\title{
Rof á hjarta eftir gangráðsísetningu - íslensk tilfellaröð
}

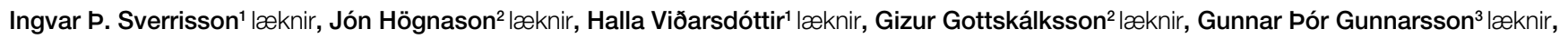
Jón Pór Sverrisson ${ }^{3}$ æknir, Tómas Guðbjartsson ${ }^{1,4} \mid æ k n i r$

\section{ÁGRIP}

Inngangur: Einn alvarlegasti fylgikvilli við gangráðsísetningu er pegar gangráðsvír rýfur gat á hjartað sem getur orsakað lífshættulega blæðingu. Lýst er 5 tilfellum sem greindust hér á landi á fjögurra ára tímabili. Efniviður og aðferðir: Farið var yfir sjúkraskrár allra sjúklinga sem greindust með rof á hjarta eftir gangráđsísetningu á Landspítala og Sjúkrahúsi Akureyrar frá 1. janúar 2007 til 31. desember 2010. Könnuð var meðferð og afdrif pessara sjúklinga.

Niðurstöður: Alls greindust 5 sjúklingar, prjár konur og tveir karlar. Meðalaldur var 71 ár. Brjóstverkur var algengasta einkennið $(n=4)$ en enginn sjúklinganna hafði einkenni um bráða hjartapröng. Greining fékkst í öllum tilfellum með tölvusneiðmynd af brjóstholi eða ómskoðun af hjarta. Ekkert rof greindist við gangráđsísetningu en fjögur tilfelli greindust innan priggja vikna eftir aðgerð. Hjá premur sjúklinganna var blóð tæmt úr gollurshúsi í gegnum bringubeinsskurð, saumað yfir gatið og nýjum gangráðsvír komið fyrir. Hjá hinum tveimur voru gangráđsvírar dregnir án skurðaðgerðar og vélindaómun notuð til að fylgjast með blæðingu í gollurshús. Einn sjúklinganna lést á gjörgæslu vegna lungnabólgu en hinir fjórir lifðu fylgikvillann af og útskrifuðust af sjúkrahúsi.

Ályktun: Rof á hjarta er hættulegur fylgikvilli sem mikilvægt er að hafa í huga hjá sjúklingum með brjóstverk eftir gangráðsísetningu.
Fyrirspurnir:

Tómas Guðbjartsson tomasgud@landspitali.is

Greinin barst 22. desember 2012, sambykkt til birtingar 6. mars 2013.

\section{Inngangur}

Gangráður er notaður í meðferð takttruflana í hjarta og eru algengustu ábendingar fyrir ísetningu hans AVblokk og sjúkur sínushnútur (sick sinus syndrome). ${ }^{1}$ Hér á landi eru gangráðsaðgerðir aðallega framkvæmdar á Landspítala (hátt í 300 aðgerðir á ári) en jafnframt á Sjúkrahúsi Akureyrar (um pað bil 10 aðgerðir á ári). Á síðustu árum hefur gangráðsísetningum fjölgað með auknum fjölda eldra fólks og víðari ábendingum, en gangráður bætir bæði líðan pessara sjúklinga og horfur. ${ }^{2}$

Algengustu fylgikvillar eftir ísetningu gangráðs eru loftbrjóst (1,4-1,8\%), blæðingar (0,5-0,9\%) og sýkingar ${ }^{3-6}$ sem oftast eru grunnar og svara meðferð með sýklalyfjum..$^{5,7}$ Við djúpar sýkingar er meðferð flóknari og getur purft að fjarlægja gangráðinn og vírana, sérstaklega ef talin er hætta á blóðsýkingu og hjartapelsbólgu. ${ }^{8}$ Aðrir pekktir fylgikvillar við gangráðsísetningar eru blóðsegi í viðbeinsbláæð og los á gangráđsvírum í hjartanu sem getur valdið lífshættulegum hjartsláttartruflunum. ${ }^{5}$ Annar hættulegur fylgikvilli er pegar vír orsakar rof á hjarta en við pað getur orðið lífshættuleg blæðing og hjartapröng (cardiac tamponade). Rof greinist stundum í aðgerð pegar vírum er komið fyrir en algengara er að pað greinist dögum eða jafnvel mánuðum síðar. ${ }^{3-6,}$ 9-11 Helstu einkenni rofs eru brjóstverkur, vökvi í gollurshúsi og gangráđstruflanir. ${ }^{10}$ Sjúklingar geta pó haft væg einkenni og lýst hefur verið tilfellum par sem rof greinist fyrir tilviljun. ${ }^{6,10,12}$

Á Íslandi hefur hjartarof eftir ísetningu gangráðs ekki verið rannsakað áður. Í pessari rannsókn eru könnuð öll tilfelli sem greindust á fjögurra ára tímabili. Notaðir voru miðlægir gagnagrunnar á sjúkrahúsum par sem pessar aðgerðir eru gerðar.

\section{Efniviður og aðferðir}

Rannsóknin byggist á tilfellaröð sem tók til allra sjúklinga sem greindust á Íslandi með rof á hjarta eftir gangráđsísetningu á tímabilinu frá 1. janúar 2007 til 31. desember 2010. Upplýsingar um sjúklinga fengust úr a) aðgerða- og greiningaskrám Landspítala og Sjúkrahúss Akureyrar, b) úr gagnagrunni hjarta- og lungnaskurðdeildar Landspítala og c) gangráðsaðgerðaskrá hjartadeildar Landspítala og Sjúkrahúss Akureyrar.

Úr sjúkraskrám voru skráð einkenni sjúklings og myndrannsóknir sem leiddu til greiningar, fylgikvillar og legutími í dögum. Skráð var ASA-flokkun (American Society of Anesthesiologists) sem metur heilsufar og klínískt ástand sjúklings fyrir aðgerð en einnig voru metin hjartabilunareinkenni með NYHA-flokkun (New York Heart Association).

Aðgerðirnar voru yfirleitt framkvæmdar í staðdeyfingu á hjartapræðingardeild eða skurðstofu af hjartalækni og skurðlækni í sameiningu. Gerður var húðskurður neðan viðbeins (oftast hægra megin) og útbúinn vasi fyrir gangráðinn í fitunni undir húðinni. Næst var einum eða tveimur gangráðsvírum komið fyrir í hægri slegli og/eða hægri gátt með hjálp gegnumlýsingar. Oftast voru vírarnir præddir í gegnum hægri viðbeinsbláæð (subclavian vein) með Seldingertækni, nema pegar komið var fyrir tímabundnum gangráð (temporary pacemaker), en pá var notast við bláæð í nára og hjartavírinn ekki festur við hjartavöðvann. Við hefðbundna varanlega gangráđsísetningu voru vírarnir hins vegar alltaf festir, annaðhvort með akkeri (passive fixation leads) eða skrúfu (active fixation leads). Eftir að búið var að mæla pröskuldsspennu og viðnám í vírunum voru peir saumaðir fastir og tengdir við gangráðinn. Sjúklingar voru síðan vaktaðir yfir nótt î 
Tafla I. Yfirlit yfir tilfelli rofs á hjarta eftir gangráđsísetningu frá 2007-2010.

\begin{tabular}{|c|c|c|c|c|c|c|c|c|c|c|}
\hline Nr. sjúkl. & $\begin{array}{l}\text { Ástæða } \\
\text { gangráðs- } \\
\text { ísetningar }\end{array}$ & $\begin{array}{l}\text { Einkenni, tímalengd fram að } \\
\text { greiningu og greining }\end{array}$ & $\begin{array}{l}\text { Hjarta- } \\
\text { pröng }\end{array}$ & $\begin{array}{c}\text { Stað- } \\
\text { setning rofs }\end{array}$ & Meðferð & $\begin{array}{l}\text { Tegund } \\
\text { leiðslu }\end{array}$ & $\begin{array}{l}\text { Pröskulds- } \\
\text { mæling }\end{array}$ & $\begin{array}{l}\text { Legu- } \\
\text { tími } \\
\text { (dagar) }\end{array}$ & $\begin{array}{c}\text { NYHA } \\
\text { ASA }\end{array}$ & Afdrif \\
\hline 1 & $\begin{array}{l}\text { Sjúkur sínus- } \\
\text { hnútur }\end{array}$ & $\begin{array}{l}\text { Skyndilegur brjóstverkur } 33 \text { mán. } \\
\text { frá gangráðsísetningu. ST-hækkanir } \\
\text { á hjartalínuriti. Á TS og hjartaómun } \\
\text { sást vökvi i gollurshúsi. Reyndist } \\
\text { einnig með kransæðasjúkdóm } \\
\text { á hjartapræđingu og gerð } \\
\text { kransæðahjáveituaðgerð samtímis } \\
\text { og gert var við rof á hjarta. }\end{array}$ & $\mathrm{Nei}$ & Hægri slegill & $\begin{array}{l}\text { Bringubeins- } \\
\text { skurður, } \\
\text { saumað yfir rof }\end{array}$ & $\begin{array}{l}\text { Skrúf- } \\
\text { leiðsla }\end{array}$ & Hrifleysa & 22 & $2 / 3$ & Lifð̈i \\
\hline 2 & $\begin{array}{l}\text { AV-blokk II } \\
\text { (Mobitz II) }\end{array}$ & $\begin{array}{l}\text { Skyndilegur brjóstverkur sem } \\
\text { versnaði við innöndun hálfum } \\
\text { sólarhring eftir gangráđsísetningu. Á } \\
\text { hjartaómun sást vökvi í gollurshúsi. }\end{array}$ & Nei & Hægri slegill & $\begin{array}{l}\text { Vír dreginn vélinda- } \\
\text { ómstýrt á skurðstofu }\end{array}$ & $\begin{array}{l}\text { Skrúf- } \\
\text { leiðsla }\end{array}$ & Hrifleysa & 9 & $1 / 3$ & Lifð̈i \\
\hline 3 & AV blokk III & $\begin{array}{l}\text { Komið var fyrir tímabundnum } \\
\text { gangráð i gegnum nárabláæð } \\
\text { og sjúklingur síðan lagður inn á } \\
\text { gjörgæslu vegna öndunarbilunar. } \\
\text { Tveimur dögum síðar kom í ljós } \\
\text { við skyggningu og „,gated“ TS- } \\
\text { rannsókn að rof var á hjartanu. }\end{array}$ & $\mathrm{Nei}$ & Hægri slegill & $\begin{array}{l}\text { Vír dreginn } \\
\text { vélinda- } \\
\text { ómstýrt }\end{array}$ & $\begin{array}{l}\text { Tímabundin } \\
\text { leiðsla í } \\
\text { gegnum } \\
\text { náraslagæơ }\end{array}$ & Hrifleysa & 2 & $2 / 4$ & Lést \\
\hline 4 & $\begin{array}{l}\text { Hægataktur } \\
\quad \text { (sinus } \\
\text { bradycardia) }\end{array}$ & $\begin{array}{l}\text { Brjóstverkur við djúpa innöndun } \\
\text { strax eftir gangráðsísetningu. Á TS } \\
\text { virtist lega gangráđsvíra eðlileg. } \\
\text { Næstu daga sást vaxandi vökvi í } \\
\text { gollurshúsi á hjartaómunum. Við } \\
\text { "gated“ TS-rannsókn kom í ljós rof } \\
\text { á hjarta. }\end{array}$ & $\mathrm{Nei}$ & Hægri gátt & $\begin{array}{l}\text { Bringubeinsskurður, } \\
\text { saumað yfir rof }\end{array}$ & $\begin{array}{l}\text { Skrúf- } \\
\text { leiðsla }\end{array}$ & $\begin{array}{l}\text { Eðlilegur } \\
\text { pröskuldur }\end{array}$ & 8 & $1 / 2$ & Lifði \\
\hline 5 & $\begin{array}{l}\text { AV-blokk II } \\
\text { (Mobitz I) }\end{array}$ & $\begin{array}{l}\text { Brjóstverkur sem versnaði við } \\
\text { innöndun tveimur dögum eftir } \\
\text { gangráđsísetningu. Hefðbundin } \\
\text { TS-rannsókn var eðlileg en á } \\
\text { "gated“ TS-rannsókn sáust greinileg } \\
\text { merki um rof. }\end{array}$ & $\mathrm{Nei}$ & Hægri slegill & $\begin{array}{l}\text { Bringubeinsskurður, } \\
\text { saumað yfir rof }\end{array}$ & $\begin{array}{l}\text { Skrúf- } \\
\text { leiðsla }\end{array}$ & Hrifleysa & 4 & $1 / 2$ & Lifð̈i \\
\hline
\end{tabular}

TS=tölvusneiðmynd.

hjartarafsjá á legudeild hjartadeildar og peim gefið léttheparín að kvöldi aðgerðar. Fyrir útskrift var fengin röntgenmynd af lungum til að staðfesta rétta legu gangráðsvíra og útiloka loftbrjóst og framkvæmt gangráðseftirlit par sem gangráðurinn var stilltur.

Upplýsingar um hvort sjúklingarnir voru lifandi eða látnir fengust úr Pjóðskrá og miðast eftirlit við 1. maí 2012. Miðgildi eftirfylgni var 23 mánuðir (bil: 0,5-34 mánuðir). Skurðdauði (operative mortality) var skilgreindur sem andlát innan 30 daga frá aðgerð. Tölvuforritið Excel var notað við úrvinnslu gagna.

Öll tilskilin leyfi frá Persónuvernd, Vísindasiðanefnd Landspítala og framkvæmdastjóra lækninga á Landspítala lágu fyrir áður en rannsóknin hófst.

\section{Niðurstöður}

Fimm sjúklingar, par af prjár konur, greindust með rof á hjarta eftir gangráðsísetningu á rannsóknartímabilinu (tafla I) og voru öll tilfellin greind á Landspítala. Eitt tilfelli greindist árið 2008, fjögur árið 2009 en ekkert árin 2007 eða 2010.

Í öllum tilvikum var um skrúfleiðslur að ræða nema í einu tilviki (tilfelli \#3) par sem rof varð eftir tímabundinn gangráðsvír. Sá sjúklingur gekkst undir bráða gangráđsísetningu á bráðamóttöku vegna hjartabilunar af völdum hægatakts.

Í töflu I má sjá nánari upplýsingar um greiningu og meðferð sjúklinganna fimm. Meðalaldur var 71 ár (miðgildi 74 ár, bil: 5184). Einn sjúklingur var í ASA-flokki 4 og hinir í flokkum 2 og 3.
Prír sjúklingar voru í NYHA-flokki I og tveir í NYHA-flokki II. Enginn sjúklinganna hafði sögu um króníska hægri hjartabilun en einn tók bólgueyðandi stera vegna lungnasjúkdóms.

Brjóstverkur var algengasta einkennið sem leiddi til greiningar rofs en enginn sjúklinganna hafði bráða hjartapröng. Hjá fjórum sjúklingum sáust truflanir í starfsemi gangráðsins á hjartalínuriti. Greining var staðfest í öllum tilfellum með tölvusneiðmynd af brjóstholi (mynd 1) eða hjartaómun. Enginn sjúklinganna greindist við gangráðsísetningu en í fjórum tilfellum var greiningin gerð innan priggja vikna frá aðgerð og hjá einum eftir 33 mánuði.

Í premur tilfellum var gerð skurðaðgerð par sem blóð var tæmt úr gollurshúsi í gegnum bringubeinsskurð, saumað yfir gatið og nýjum gangráđsvír komið fyrir (mynd 2). Hjá hinum tveimur voru gangráðsvírar dregnir á skurðstofu og vélindaómun notuð til að fylgjast með blæðingu í gollurshúsi. Í báðum pessum tilfellum var blæðing óveruleg og ekki purfti að grípa til skurðaðgerðar. Fjórir sjúklingar lifðu af meðferðina og útskrifuðust af sjúkrahúsi. Peir voru allir á lífi við eftirlit pann 1. maí 2012. Einn sjúklingur lést (tilfelli \#4) en par var um að ræða 83 ára gamla konu sem lést á gjörgæslu úr lungnabólgu sem ekki var rakin beint til ísetningar gangráðsins.

\section{Umræða}

Pessi tilfellaröð er fyrsta íslenska rannsóknin á rofi á hjarta eftir ísetningu gangráðs. Í erlendum rannsóknum er tíðni rofs yfir- 


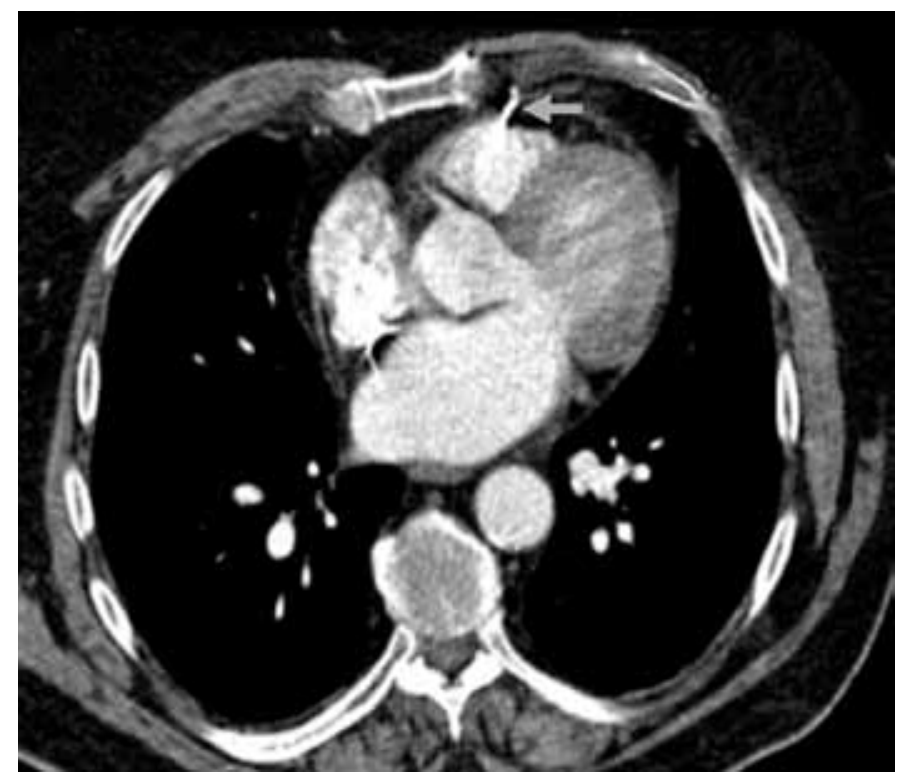

Mynd 1. Tölvusneiðmynd (tilfelli \#3) sem sýnir hvernig gangráđsvír hefur rofið gat á hægri slegil (ör).

leitt á bilinu 0,1-0,8\% en hafa verður í huga að skilgreining rofs getur verið breytileg milli rannsókna. ${ }^{6,9,13}$ Pað var ekki markmið okkar að rannsaka sérstaklega tíðni rofs eftir gangráðsísetningu á Íslandi enda um tilfellaröð að ræða á aðeins fjögurra ára tímabili. Hægt er pó að áætla tíðnina gróflega á pessu tímabili, pví samkvæmt skrám Landspítala og Sjúkrahússins á Akureyri voru á pessum fjórum árum gerðar 1119 gangráðsaðgerðir, par af 104 með tímabundnum gangráð. Tíðni rofs var pví í kringum 0,4\% á pessum fjórum árum, sem er sennilega í hærra lagi par sem óvenjumörg tilfelli greindust árið 2009. Við kunnum ekki skýringu á pví af hverju svo mörg tilfelli greindust á pví ári og er sennilega um tilviljun að ræða. Í einu tilviki var um tímabundna gangráðsleiðslu að ræða sem prædd var í gegnum nárabláæð hjá fjölveikum sjúklingi sem fengið hafði meðferð með bólgueyðandi sterum. Í hinum tilfellunum fjórum var notast við skrúfleiðslur og augljósir áhættupættir rofs ekki til staðar.

Á síðustu árum hafa skrúfleiðslur notið vaxandi vinsælda enda auðvelt að koma peim fyrir í hjartavöðvanum. Skrúfleiðslur eru hins vegar stífari í endann en akkerisleiðslur ${ }^{10,13}$ og hafa nokkrar rannsóknir sýnt fram á hærri tíðni rofs. ${ }^{3,9,10,13}$ Við bjargráðsaðgerðir er yfirleitt hærri tíðni rofs en við gangráðsaðgerðir eða allt að 0,6$5,2 \%,{ }^{6,9,13}$ og skýringin talin vera pykkari og stífari vírar. ${ }^{6}$

Allir sjúklingarnir 5 höfðu einkenni sem rekja mátti til rofs á hjartavöðvanum. Í framskyggnri rannsókn Hirschl og félaga var fylgst með 100 sjúklingum eftir gangráðsísetningu og sáust merki um rof á tölvusneiðmyndum í 15\% tilfella. Athyglisvert er að flestir pessara sjúklinga voru án einkenna og ekki með greinanlegar truflanir á starfsemi gangráđsins. ${ }^{6}$ Tveir okkar sjúklinga greindust með rof eftir útskrift af sjúkrahúsi, annar tveimur sólarhringum frá aðgerð og hinn 33 mánuðum síðar. Hin prjú tilfellin uppgötvuðust í sömu sjúkrahúslegu en enginn hafði einkenni um hjartapröng. Erlendis hefur síðbúnum rofum verið lýst líkt og í okkar rannsókn, oft í kjölfar gangtruflana eða vegna brjóstverkja eða mæði. ${ }^{910}$ Hjá fjórum okkar sjúklinga sáust truflanir í gangráðsmælingu en í mörgum stærri rannsóknum er slíkum truflunum lýst í flestum tilvika rofs. Enn eru ekki komnir á markað

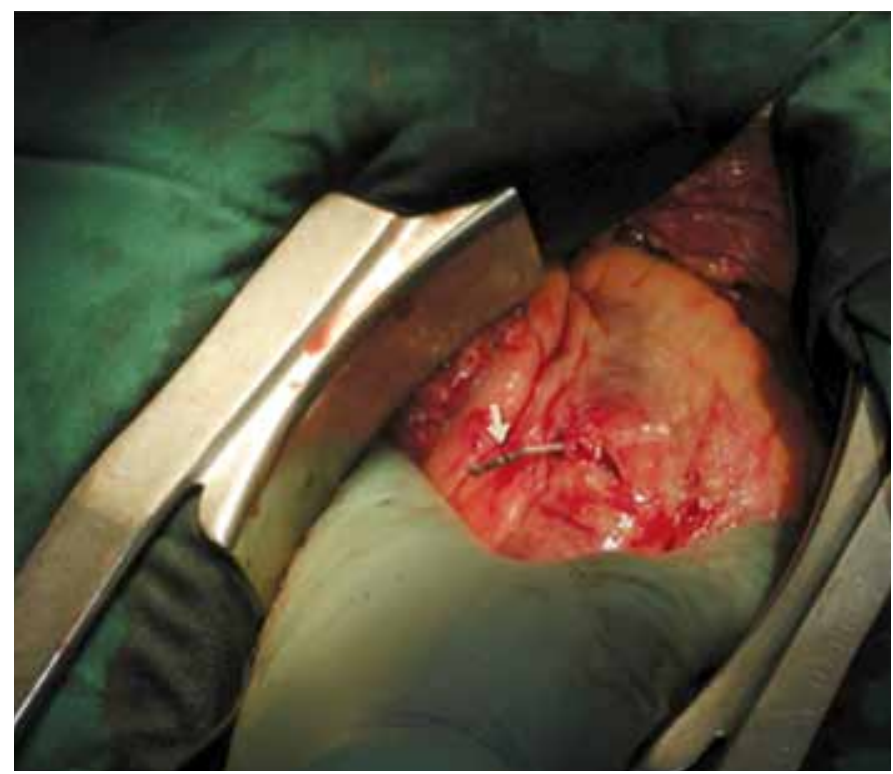

Mynd 2. Mynd úr skurðaðgerð (tilfelli \#4). Í gegnum bringubeinsskurð sést hvernig gangráđsvírinn hefur stungist í gegnum framvegg hægri slegils (ör).

gangráðar sem greina slíkar truflanir og vara sjúklingana við ${ }^{10}$ en slíkur búnaður gæti komið á markað innan fárra ára.

Í flestum rannsóknum eru rof algengari á hægri gátt en slegli og er skýringin talin vera sú að veggur gáttarinnar er pynnri en í sleglinum. ${ }^{6}$ Í okkar rannsókn var pessu öfugt farið en aðeins greindist eitt tilfelli með rofi á gátt. Staðsetning gangráðsvírs í hjartanu getur haft áhrif á tíðni rofs, til dæmis er talið að vírar á hliðarvegg gáttar orsaki frekar rof en pegar peir eru festir á gáttarskipt (septum). ${ }^{3}$

Í premur tilfellanna var saumað fyrir rofið í opinni aðgerð og vírinn fjarlægður um leið. Tveir pessara sjúklinga höfðu töluvert magn blóðs í gollurshúsi á hjartaómun og pví talið öruggast að gera aðgerðina í gegnum bringubeinsskurð. Í priðja tilfellinu kom í ljós útbreiddur priggja æða kransæðasjúkdómur og pví gerð hjáveituaðgerð um leið og gert var við rofið. Í hinum tilfellunum tveimur var ekki gerð skurðaðgerð, en pess í stað var vírinn dreginn á skurðstofu og vélindaómun notuð til að fylgjast með blæðingu út í gollurshúsið. Auk pess var komið fyrir kera í gollurshúsinu og pannig fylgst með blæðingu. Pessari aðferð hefur verið lýst áður ${ }^{9,10,13}$ en rannsóknir á árangri hennar vantar. Ástæða pess að vírarnir eru fjarlægðir á skurðstofu er að opna getur purft sjúklinginn tafarlaust ef blæðing er mikil.9,13 Vel gekk að fjarlægja vírana með pessum hætti í báðum tilfellum og blæðing var óveruleg. Annar sjúklingurinn lést premur dögum síðar á gjörgæslu vegna lungnabólgu og öndunarbilunar. Dánarorsök var pó ekki rakin beint til rofs á hjartanu en rofið getur pó hafa ýtt undir veikindi sjúklingsins sem var með alvarlega hjartabilun áður en gangráðnum var komið fyrir.

Styrkleiki pessarar rannsóknar er að hún tekur til heillar pjóðar en hér á landi eru allar gangráðsaðgerðir framkvæmdar á tveimur sjúkrahúsum. Petta minnkar líkur á pví að tilfelli hafi gleymst en notast var við 5 aðskildar skrár. Aðeins er um tilfellaröð að ræða og veikleiki hversu stutt rannsóknartímabilið er.

Æskilegt væri að skrá fylgikvilla gangráðsaðgerða hér á landi, par á meðal rof, með framskyggnum hætti líkt og tíðkast víða erlendis. 


\section{Heimildir}

1. Eltrafi A, Currie P, Silas JH. Permanent pacemaker insertion in a district general hospital: indications, patient characteristics, and complications. Postgrad Med J 2000; 76: 337-9.

2. Birnie D, Williams K, Guo A, Mielniczuk L, Davis D, Lemery $\mathrm{R}$, et al. Reasons for escalating pacemaker implants. Am J Cardiol 2006; 98: 93-7.

3. Geyfman V, Storm RH, Lico SC, Oren JW. Cardiac tamponade as complication of active-fixation atrial lead perforations: proposed mechanism and management algorithm. Pacing Clin Electrophysiol 2007; 30: 498-501.

4. Dilling-Boer $\mathrm{D}$, Ector $\mathrm{H}$, Willems $\mathrm{R}$, Heidbuchel $\mathrm{H}$ Pericardial effusion and right-sided pneumothorax resulting from an atrial active-fixation lead. Europace 2003; 5 : 419-23.
5. Aggarwal RK, Connelly DT, Ray SG, Ball J, Charles RG. Early complications of permanent pacemaker implantation: no difference between dual and single chamber systems. Br Heart J 1995; 73: 571-5

6. Hirschl DA, Jain VR, Spindola-Franco H, Gross JN Haramati LB. Prevalence and characterization of asymptomatic pacemaker and ICD lead perforation on CT Pacing Clin Electrophysiol 2007; 30: 28-32.

7. Kiviniemi MS, Pirnes MA, Eranen HJ, Kettunen RV, Hartikainen JE. Complications related to permanen pacemaker therapy. Pacing Clin Electrophysiol 1999; 22 711-20.

8. Klug D, Lacroix D, Savoye C, Goullard L, Grandmougin D, Hennequin JL, et al. Systemic infection related to endocarditis on pacemaker leads: clinical presentation and management. Circulation 1997; 95: 2098-107.
9. Khan MN, Joseph G, Khaykin Y, Ziada KM, Wilkoff BL. Delayed lead perforation: a disturbing trend. Pacing Clin Electrophysiol 2005; 28: 251-3.

10. Laborderie J, Barandon L, Ploux S, Deplagne A, Mokrani B, Reuter S, et al. Management of subacute and delayed right ventricular perforation with a pacing or an implantable cardioverter-defibrillator lead. Am J Cardiol 2008; 102: 1352-5.

11. Ellenbogen KA, Wood MA, Shepard RK. Delayed complications following pacemaker implantation. Pacing Clin Electrophysiol 2002; 25: 1155-8.

12. Aliyev F, Celiker C, Turkoglu C, Karadag B, Yildiz A. Perforations of right heart chambers associated with electrophysiology catheters and temporary transvenous pacing leads. Turk Kardiyol Dern Ars 2011; 39: 16-22.

13. Satpathy R, Hee T, Esterbrooks D, Mohiuddin S. Delayed defibrillator lead perforation: an increasing phenomenon. Pacing Clin Electrophysiol 2008; 31: 10-2.

\section{ENGLISH SUMMARY}

\section{Cardiac perforation following pacemaker implantation - a case series from Iceland}

Sverrisson ITh', Hognason J², Vidarsdottir $\mathrm{H}^{1}$, Gottskalksson $\mathrm{G}^{2}$, Gunnarsson $\mathrm{GTh}^{3}$, Sverrisson $\mathrm{JTh}^{3}$, Gudbjartsson $\mathrm{T}^{1,4}$

Introduction: Perforation of the heart is a serious complication following pacemaker implantation that can cause life threatening bleeding and cardiac tamponade. Here we describe five cases that were diagnosed in Iceland during a four year period.

Materials and methods: This population-based case series includes five patients diagnosed with cardiac perforation following pacemaker insertion at Landspítali and Akureyri Hospital from January 1, 2007 to December 31, 2010. The mode of detection, treatment given and outcome were studied.

Results: Altogether five patients (mean age 71 years, three females) were diagnosed with cardiac perforation in Iceland during the study period, one in 2008 and four in 2009 . Chest pain was the most common presenting symptom $(n=4)$ and no patient had acute cardiac tamponade. In all five cases the diagnosis was obtained with computed tomography scan or echocardiography. No perforation was detected intraoperatively but four of the cases were diagnosed within three weeks of the operation. Three patients were treated with surgical evacuation of blood via sternotomy and suture of the perforation. In the other two cases the pacemaker leads were removed in the operating room with trans-oesophageal echocardiographic guidance. Four patients survived the treatment and were discharged but one died of pneumonia in the intensive care unit.

Conclusion: Cardiac perforation is a serious complication and should be kept in mind in patients with chest pain following pacemaker insertion.

Key words: Pacemaker implantation, cardiac perforation, complications, treatment, mortality.

Correspondence: Tómas Guðbjartsson, tomasgud@landspitali.is

${ }^{1}$ Departments of Cardiothoracic Surgery and ${ }^{2}$ Cardiology National University Hospital of Iceland, Reykjavik. ${ }^{3}$ Department of Internal Medicine, Akureyri Hospital, ${ }^{4}$ Faculty of Medicine, University of Iceland. 